\title{
EARTHQUAKE FAILURES ON BUILDINGS AND THE ROLE OF ARCHITECT ON BUILDING SAFETY
}

\author{
Noor Cholis Idham \\ Architecture Department, Universitas Islam Indonesia \\ Email: noor.idham@uii.ac.id
}

\begin{abstract}
The safety of building users against earthquakes is not directly caused by earthquakes, but rather by the ability of the people and environment to deal with the shake. The failure of the building is the most causing factor for the casualties and property losses. However, the building structural strength is not the single decisive aspect of building safety but also accompanying by others such as building design and the use of architectural elements. This paper explores the various failures after earthquakes and its relationship with architecture designs as the work of architect in the building process. The discussion is conducted based on the type of the failures, the causing factor of the damages, and how the builders should anticipate it. The results of this study show that the main principles relating to the safety of buildings are closely related to architects who play a significant role in building design starting from the decision of the location, choosing the appropriate building type, designing less vulnerable structure, and avoiding the complexity in building design. Architects are expected to increase the safety of building users by their devoted responsibility for avoiding the unnecessary casualties.
\end{abstract}

Keywords: Earthquake failures; Building safety; Architect role.

\section{INTRODUCTION}

Earthquake occurrence is unavoidable but could be anticipated so that adverse impacts on the human and environment is minimal. The quakes are proven not as the primary cause of the human's life, but the failure of the buildings is usually resulting many casualties (Idham, 2014). The death causing by the building is up to $75 \%$ (Coburn, Spence, \& Pomonis, 1992). The building safety is then the critical task that must be prepared with the primary objective of minimizing fatalities. The principle of buildings safety under earthquake allows the buildings to crash and even collapse but the protection of the user should be retained. Many casualties were caused either directly by the structural or architectural deficiencies. The architectural failure such as collapsed wall or failed roof were even counted as the main causing factor resulting the fatality such as Bantul earthquake in 2006 where more than 6000 people death and hundred thousand buildings collapsed (Idham \& Mohd, 2018). For this purpose, the safety concepts as part of comprehensive building design must be more considered.

The magnitude of the earthquake is not the single factor of destructive energy but combined with the load of the building and its environmental factors. In case of two major earthquakes of Sumatra 9.1 Mw December 2004 and the Sumatra earthquake $8.6 \mathrm{Mw}$ April 2012, the impact on the building was different. The 2004 earthquake was devastating and even triggered an enormous tsunami that reached the mainland of Africa and death toll reached 286,000 people, while the 2012 earthquake did not cause significant damage to buildings in the immediate vicinity with only two casualties (USGS, 2018) (table 1). An earthquake will affect the building due not only to the strength of an earthquake called moment magnitude (Mw) but also how that energy is passed to the site where the building is located (BGS, 2018). The nature of the energy source, the distance, the depth of the hypocenter, as well as the geographic and geological conditions to the closest built environment (building) significantly affect the destructing power level of an earthquake.

Building problems under the earthquake, up to this moment, are commonly addressed to experts in the field of structures rather than the others. The impact of earthquakes on buildings is often only discussed on technical matters related to the calculation of building strength. It is certainly understandable, but not totally right since the safety of a building users is not determined solely by the strength of the structure, but also the overall concept of the building design.

Table 1. Comparison of two large Sumatra quakes. source: (USGS, 2018)

\begin{tabular}{lcc}
\hline Parameter & $\begin{array}{c}\text { Sumatra Earthquake } \\
\text { December 26, 2004 }\end{array}$ & $\begin{array}{c}\text { Sumatra Earthquake } \\
11 \text { April 2012 }\end{array}$ \\
\hline Location & $2,311^{\circ} \mathrm{N}, 93,063^{\circ} \mathrm{E}$ & $3.316^{\circ} \mathrm{N}, 95.854^{\circ} \mathrm{E}$ \\
Magnitude & 9.1 & 8.6 \\
Depth & $22.9 \mathrm{~km}$ & $30 \mathrm{~km}$ away \\
Distance to & $250 \mathrm{~km}$ southeast & $434 \mathrm{~km}$ southwest \\
Banda Aceh & & \\
\hline
\end{tabular}

In addition, the building may have been calculated on the basis of a complete structural analysis, but 
in fact, a moderate to big earthquake almost always knocked down buildings and still took casualties from previously thought to be sturdy buildings. The example of this condition can be found from the number of damage that cost thousands of lives more than 15,000 lives and over 120,000 buildings destroyed from the 9.0 earthquake and tsunami of Tōhoku earthquake in Japan 3 March 2011 (Oskin, 2018), though it is known as the country with the most buildings prepared for the earthquake. The Fukushima nuclear reactor was damaged seriously even though the building was $100 \%$ planned to be safe against the earthquake. These prove that structural calculation is not the only major consideration in designing earthquake-safe buildings.

The facts that the earthquake impact is fascinating and should be examined on how it actually destructs the building. The nature and character of the earthquake energy and the damage caused is very significant to learn, especially for architects since the failures were caused not only by structural strength but also involving aspects in building design related to the form, size, construction, and configuration. For this reason a discussion on the matters are absolutely necessary for architects in order to reduce the impact of the earthquake causing a disaster for the human environment.

\section{METHODOLOGY}

This study is aimed to increase awareness of architects related to the importance of architectural design deals with an earthquake. Building failures under an earthquake are essential to be examined by firstly exploring the destructing factors of the earthquake, the impacts to the buildings, the building failures, and the architectural design interrelated. Many cases from some sources including engineered building and vernacular houses were utilized to collect the whole picture of the failures and building designs. Architect role is then concluded from the discussion by the fact of the failures on some previous earthquake occurrences.

\section{RESULTS AND DISCUSSION}

The earthquake intensity is expressed in units of Modified Mercalli Intensity scale (MMI) which is intended to measure the effect of an earthquake on the human environment. The intensity is influenced by many aspects besides the magnitude such as (a) the distance of the hypocenter or epicenter, (b) influence of the soil type, (c) earthquake duration, and the building structure (USGS, 2016). Magnitude is the scale of earthquake energy released at the hypocenter of the earthquake. The engineered building is expected will damage in the 5 SR earthquake (Idham, 2014; USGS, n.d.), however the building quality or environmental aspect is vary and the damage may start below or above 5 magnitude.

The intensity of the earthquake is affected by the distance and depth (hypocenter) as well as the horizontal distance (epicenter) of the source which is divided into shallow and deep earthquakes. Earthquake's source from more than $70 \mathrm{~km}$ below the earth's surface (below the thickness of the earth's crust) is categorized as a deep earthquake and from distances of $200 \mathrm{~km}$, or more are grouped as distant quakes (Smart, n.d.; Spence, Sipkin, \& Choy, 2018) which are less impact on the human environment. Large magnitudes will be meaningless if it occurs in depths or away from building sites due to their small amplitude which is weakening. Conversely, although the magnitude of the earthquake is small, if the earthquake happens close enough to the building or shallow, then it will influence significantly to the building. For example, the Yogyakarta earthquake of 2006, with only 5.9 SR (BMG) or 6.3 M (USGS) many buildings destroyed by near and shallow $( \pm 10$ $\mathrm{km})$ earthquake sources.

The harder the ground, the faster the wave propagation passes, while soft soil slows down wave velocity and converts it into motion energy. Amplification of the wave will occur at the acceleration of movement on the ground (wave <600 ft. / sec) (Silva, 1997; Spence et al., 2018). The soil properties besides determining the propagation of the waves also determine the natural shaking vibrations of the soil which are strongly associated with passing energy. Earthquakes have different durations depending on the type of collapse and fault properties that occur. The time-span of shock will significantly affect the intensity of the building. Small shakes in a long time can damage the building, and high duration of vibration will significantly affect the durability of materials and building structures. Similarly, aftershocks that occur after the main earthquake though with small strength may impact to more damaging to buildings since they have been affected by the previous major earthquake.

\section{EARTHQUAKE ENERGY AND DAMAGE OF THE BUILDING}

The wave of an earthquake is a form of energy which is strongly influenced by the way it travels from the source to the human environment on the surface of the earth. The main aspects of the 
earthquake's shake in buildings include the duration of the quake, amplitude, and frequency (Ghaidan, 2002). The related aspects with their physical properties are (a) frequency and amplitude, (b) acceleration, and (c) resonance (JIA-JASO, 2015).

\section{Frequency and Amplitude}

The frequency of the earthquake wave is inversely proportional to the amplitude. Earthquakes shake with a high-frequency wave are identic with a low amplitude and vice versa. Amplitude is an earthquake property associated with strength or weakness of the energy because it affects the soil and building vibrations. The amplitude is determined by the distance of the hypocenter and epicenter, or distance and depth of the source of the earthquake. The nearer or shallower the source of the earthquake, the higher the amplitude and the higher the vibration of the energy. The dominant frequency 1-0.1 hertz extend in surface ground wave (Britanica, 2018).

Surface waves are more dangerous than underground waves because they have a high amplitude with a low frequency. A high amplitude causes intense physical movement of the soil, and a low frequency more likely to cause damage to the buildings. The sideways movement appears with the amplitude from 1 to $70 \mathrm{~mm}$ for regular earthquakes and up to $240 \mathrm{~mm}$ for strong earthquakes. An earthquake with 3 Richter scale (SR) will sway a building as wide as $1 \mathrm{~mm}$ in the location as far as 100 $\mathrm{km}$ from epicenter and will be doubled for every $1 \mathrm{SR}$ increments (Krisnanto, 2009). Damage to the structural system generally occurs with the occurrence of amplification caused by the phenomenon of resonance with natural vibration frequencies of the building.

\section{Acceleration}

Buildings can generally retain acceleration as a form of the gravity $(1 \mathrm{~g}=9.8 \mathrm{~m} / \mathrm{sec})$, but if this load occurs horizontally, then almost all buildings will collapse instantly. Acceleration in buildings from zero to several meters per second will cause structures, especially with high masses, likely to retain their positions so that building strength is crucial. For example, an earthquake acceleration of 3-5 m/sec $2( \pm$ $0.5 \mathrm{~g}$ ) in the Yogyakarta earthquake of 27 May 2006 (Poland, 2010) can destroy non-technical buildings quickly. Due to the sediment soil conditions that are soft, the acceleration is even doubled in the area near the source of the earthquake (Walter et al., 2008) or $0.20 \sim 0.34 \mathrm{~g}$ in the horizontal direction up to $3.5 \mathrm{~g}$ in the vertical direction (Amr S Elnashai, Kim, Yun, \&
Sidarta, 2007), so the impact is that almost none of the buildings survives in the area.

\section{Earthquake Resonance}

Earthquake waves may occur with a variety of frequencies that are very likely equal to the natural frequencies of man-made environments. The buildings will react with the same particular frequency according to its natural occurrence or called resonance (IRIS, n.d.). The resonant effect will enlarge the movement and force the building so that the possibility of building damage will be greater.

A lower building has higher natural frequencies while high rise building has the low frequencies. The natural frequency of buildings is $0.1 \mathrm{sec}$ (in one second ten vibration periods) per floor. Thus the structure of one, 10, 30 floors has a frequency of 0.1 , 1,3 sec respectively; the higher the building, the lower the natural frequency. Short or rigid buildings will be affected more in high-frequency earthquakes whereas low-frequency earthquakes will have more effect on tall buildings or buildings with flexible materials. Very high buildings will be relatively safe from earthquake shocks as they move away from the natural frequency of the earthquake.

Earthquake waves close to the source still have high energy with high frequencies compared to locations far away from the earthquake. Therefore the low and rigid buildings are precisely the most vulnerable to near quakes compared to multi-story buildings. Besides due to the amplitude, a low and rigid building is also vulnerable to the resonance due to the high frequency. Many destructed houses under earthquake such as Yogyakarta earthquake of 27 May 2006 which was not so large in magnitude but has a hypocenter close to the residential building area had given rise to this resonance.

\section{EFFECT OF THE QUAKE ON BUILDINGS}

The final determinant of the earthquake intensity level against the building is the design of the building itself. In the case of earthquake-damaged buildings, they are mostly caused by the unpreparedness of the building of the lateral loads. In general, the building is not designed for earthquake shocks, but only on the weight of the functions and the building weight itself. The design of the building against the earthquake is mainly influenced by the characteristics of the structure that includes: (a) Natural vibration time of building structure, (b) Damping of the building structure, (c) Requirements and concepts of building and detailing. 
The natural vibration or frequency, as discussed earlier, is more affected by the height of the building, the structural system, and the building materials used. Tall buildings with flexible structures have a lower frequency than rigid low-buildings. Damping is more related to the primary system or addition to the building structure as well as rigid wall structures and bracing. The flexible foundation pads are also categorized in this attenuation.

Earthquake vibration is the movement of the soil on the foundation of the building that causes it to move while the top of the building tends to remain because it maintains its mass potential load. The higher the movement energy and the amplitude of the earthquake, the higher the movement of the lower part of this building so that the upper building tends to experience more displacement or position difference compared to the bottom. This position difference will affect the mechanism of channeling the forces that occur to affect the building integrity. Because of the process, the upper parts of the building tend to be damaged first and the vertical parts such as the columns and walls, are the most affected part of the building which bends like cantilever construction on the vertical load.

Earthquake movement on the land unfortunately not once but repeatedly according to the duration of the earthquake accompanied by changes in acceleration. The acceleration changes make the building accepts the vibration energy of the ground and disrupts the stability of the building. The impact of this phenomenon is the destruction of building element material because it cannot withstand with acceleration load. The building is vulnerable to collapse because its stability is disrupted.

Dynamic movement of soil caused by the earthquake's vertical and lateral force on the building but the lateral force movement has the most damaging effect on the building. In contrast, vertical forces are usually less significant to damage buildings (Hamburger \& Scawthorn, 2006). This condition certainly does not apply to buildings that are relatively located near the epicenter because the effects of vertical force will be quite high and are more damaging to buildings due to $\mathrm{R}$ waves as discussed earlier. Effect vertical gravitational forces and lateral force effects combined with earthquakes cause overturning moments or upside-down moments in buildings. The more weight the building, the higher the potential of this moment (Ghaidan, 2002). Location of the building is crucial for this issue.

\section{BUILDING FAILURES AND ARCHITECTURAL DESIGN PRINCIPLES}

Structural damage usually does not occur until the magnitude of $5.0 \mathrm{Mw}$ which generally as the result of a failure on the ground, structural vibration, and other causes (Yashinsky, 2006). The failure of the building under an earthquake is generally caused by the inability of the parts of the building to work as a system in opposing lateral forces (A.S. Elnashai \& Di Sarno, 2008). The selection of materials has also the important role to safe the building.

Some aspects of building failure due to earthquakes relate to design errors which affect the performance of structural systems are the strength, rigidity, and flexibility; improper element connections; the quality of workmanship and materials; and the failure of the soil (BGS, 2018; Giuliani, 2000; Murty, Goswani, Vijayanarayanan, \& Mehta, 2012; White, n.d.).

\section{Light Structure}

The massive building of adobe and reinforced concrete houses will trigger greater inertia during an earthquake because the inertial amplitude will directly proportional to the mass of the structure (Figure.1). The secure building then identic with a light-weight structure such as timber or metal construction. Wooden structure such as Joglo is better to deal the quake rather than heavier structure (Maer, 2009; Prihatmaji, 2007). Brick wall houses and RC construction, which is massive, is less suggested for secure building from earthquakes. Masonry building are accounted for most of the building failure up to $70 \%$ (Coburn et al., 1992).
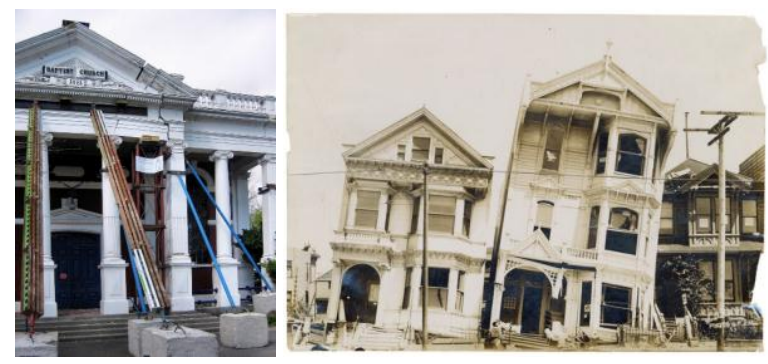

Fig. 1. Structures with heavy materials will always vulnerable to earthquakes New Zealand 2011 and the surviving wooden structure did not collapse instantly in the event of the 1906 San Francisco earthquake (photo: Martin Luff and US National Archives).

\section{Flexible buildings}

Building structures with short vibration periods will have more swings in the event of an earthquake. This type of building structure generally has a high degree of vulnerability unless it uses a stronger structural system. Brittle buildings were damaged quickly and concrete building failures were the most causing casualties compared to any other 
structural system (Coburn et al., 1992). Short buildings with rigid building materials are particularly vulnerable to short vibration periods (Figure.2). Relatively tall building with flexible structure should be utilized to avoid short-vibration effect since the frequency of those building is less and the swing of the building caused by the small amplitude of the wave. If small or rigid building should be used, the reinforcement should be extra. Again, RC structure in a non-multi-story building is less suggested.



Fig. 2. Low buildings damaged resonated with the high frequencies (photo: Martin Luff)

\section{Integrated Structure}

Building failures can be avoided by the use of building elements that support vertical load systems without the brittle materials. If not, then a high reinforcement should be given and the construction mass should be reduced. High deformation capabilities can be achieved through the use of flexible structural elements to delay collapse. The reinforcement both for a rigid or flexible frame is needed more. Bracing is commonly used for steel building while extra reinforcement in RC joints is needed.

\section{Building with space in between}

Failure due to the fragile material will affect other structural elements with the similar mode. The building will collapse from the floor where the fragile element has failed and will cause more consecutive failures, though other elements are relatively better, which is referred to as a progressive failure of brittle due to the vertical elements (Figure.3). Neighborhood homogeny is needed to prepare the buildings will react similarly. The space between adjacent building is also needed to keep the buildings have space with its nature without affecting others (BGS, 2018). The fail from one building will not cause others, and progressive collapse can be minimized.

The hammering or punch effect may happen for many times in correlation with the intensity of the earthquake. The collision between the two buildings will damage both structures, especially the relatively weaker ones. The collision generally occurs in crowded urban buildings or improper building configurations (Figure.3). Building arrangement by keeping enough space in between to expect the sway under quake is urgent to keep every building react freely without affecting each other.

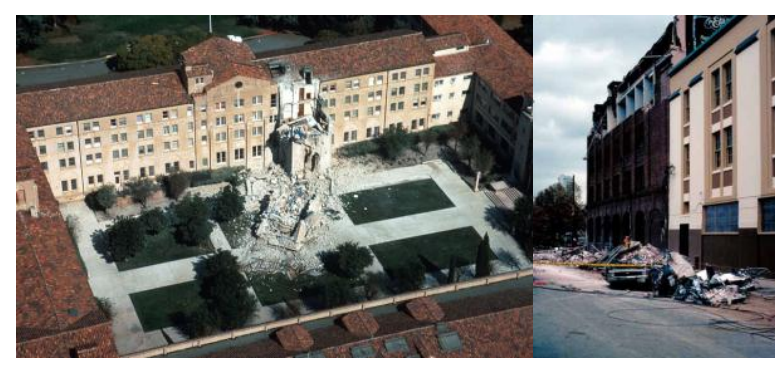

Fig. 3. The adjacent buildings will destroy the weaker one (photo: Wilshire and Meyer USGS)

\section{Homogeny Structure}

High-strength connections between vertical elements are required to overcome the damage of the vertical element and move it to the horizontal element. This principle is known as the strong column-weak beam which is intended to protect the main elements of the building as a structural buffer to delay further collapse (Figure.4). The connection is the critical part of the system to hold the entire building under the quake. It should be designed stronger rather than the elements in a building. It is also very urgent to arrange the space of the building as multiplying primary module, so the dimension of the structural elements such as column or beam is homogeny (Giuliani, 2000). Damage on the different size which called as short column effect can be minimized with the consistency in structural element dimension.

Earthquake-induced deformation usually occurs in certain aspects such as at the floor level where the high deformity and or weakness is found. This weak floor is known as a soft story as a result of wide openings on the floor (Guevara-Perez, 2012). It is common in commercial or residential buildings on the ground floor (Figure 5). The ground floor should not be opened as much as all the walls are removed to deal with the matter. Some of the walls are still needed to hold the lower system is not experiencing the over-deformation, or some structural reinforcement must be added to act similarly such as bracings or additional joint strengthening. 

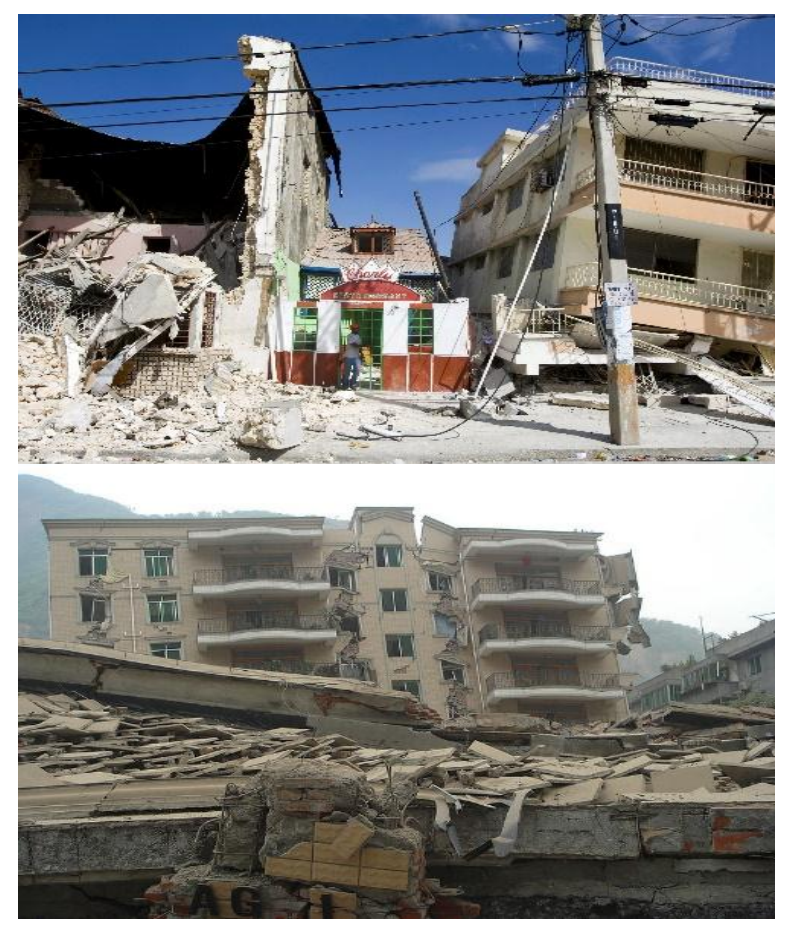

Fig. 4. Building damage to column failure (left) and beam failure (right) (photo: Marco Domino)

\section{Vertical-Continuous Building}

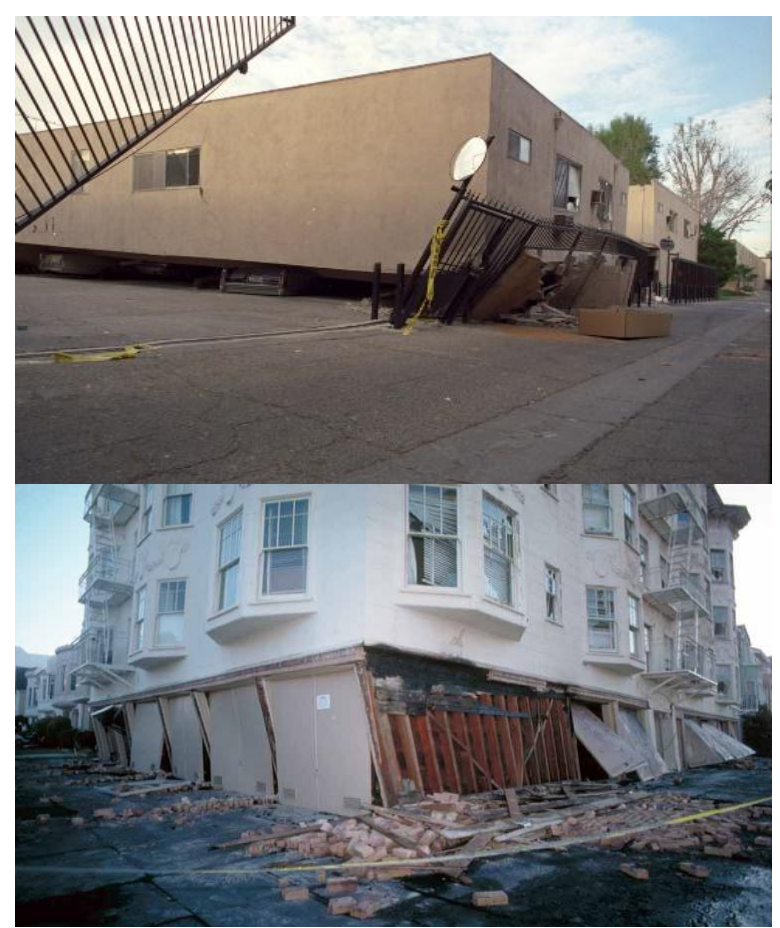

Fig. 5. The impact of the earthquake due to the soft story effect on the building ground floor (photo: Gedstrom and Nakata USGS)

Column inconsistency may cause other vertical irregularities on each floor, unequal or un-continuous weights from floor to floor, or even short columns caused by different levels of the floors in high rise buildings (Figure.6). Architects are suspected of causing the failures since most of them tend to like as 'different' or as 'spectacular.' Plans should be arranged typically in every floor, and the columns must support in line accordingly. If accentuation is needed, a particular treatment should be done to support the load concentration on the spots.

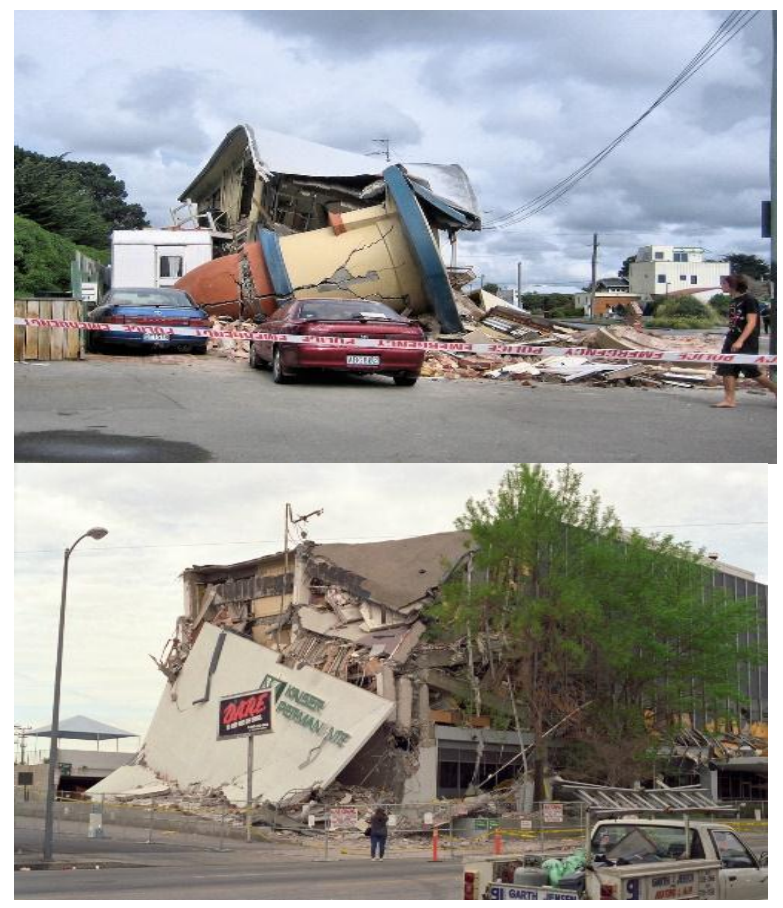

Fig. 6. The failure of heavy elements on the upper floors such as tower roof (left) and wall element (right) in Christchurch 2011 earthquake (photo: Martin Luff)

\section{Simple Plan Building}

Horizontal deviations can be found in an asymmetric building plan because of inequality load between the center of the mass and its outer parts which causing the twisting vibration during the earthquake. More severe damage is expected to occur in building elements on that floor plan and parts of buildings that have a long distance from the center of the mass (Figure.7,8). Compacted plan and mass are needed to avoid building parts overture under the vibration (Giuliani, 2000; Murty et al., 2012). If complicated masses are wanted, the mass segregation should be taken by the structural separation or known as dilatation.

Architectural elements can reduce the performance of the structural systems such as wide openings, heavy tanks on the roof, and massive walls. They contribute significantly to the stiffness of the structural system. If this element does not lie in the balance position, it can cause system failure. The 
architectural elements can also cause fatal consequences for falling easily such as walls, ceilings, interior elements, and decoration (Figure.9). Architects should make sure that building elements are secure by not exaggerating the openings, anchoring architectural element, and putting the heavy elements in the building balance.

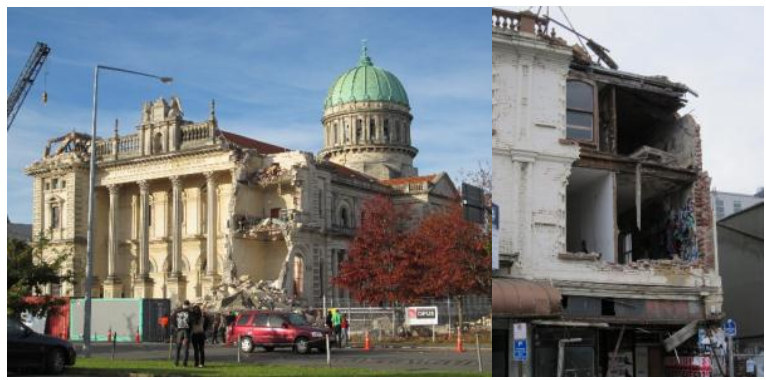

Fig. 7. Damage in the outer elements are generally occurs in the corner of the building (photo: Martin Luff)
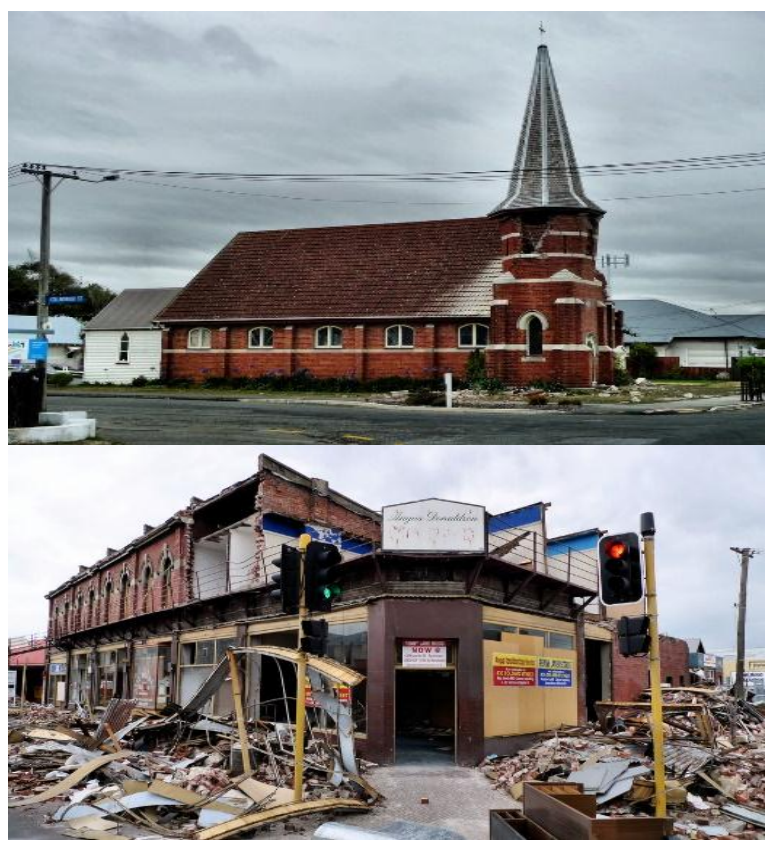

Fig. 8. The asymmetric plan makes the torsional effect on the building (photo: Martin Luff)

\section{The simple architectural elements}

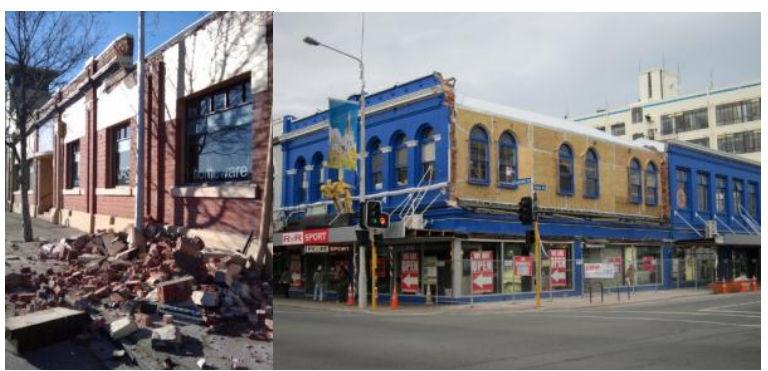

Fig. 9. The architectural elements of the parapet or walls of the building's fallen (photo: Martin Luff)

\section{Right Location}

Foundation failure causes significant damage to the building even if the main building itself is not dented. The foundations can experience failure generally due to landslides, liquefaction, crushed valleys, soil compaction, and differential forces (Figure.10). Choosing the safe site is imperative to make sure the building still stand from the soil defects. Otherwise, very sturdy foundations must be applied in the buildings.

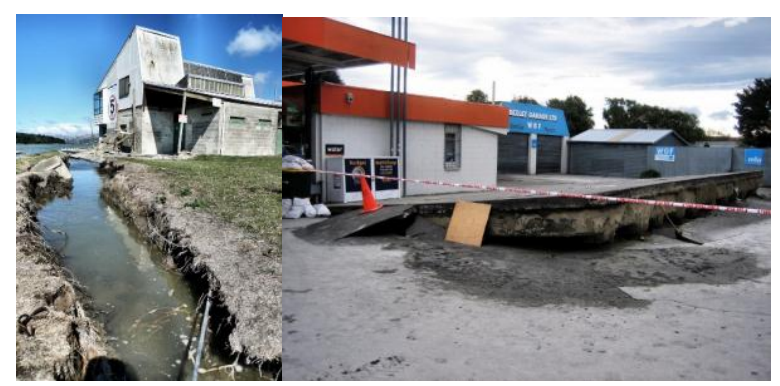

Fig. 10. The foundation failures due to the ground (left) and the liquefaction effect (right) (photo: Martin Luff)

\section{Building Maintenance}

Impaired of age and environmental condition will damage the structural material and will directly reduce the seismic performance of the building. Maintenance is the critical factor to keep the quality of the material and system. Unfortunately, in many cases, building maintenance is still less considered especially in rural housing.

\section{BUILDING FAILURES ON NON-ENGINEERED HOUSES}

Yogyakarta earthquake on May 27, 2006, was causing many failures of traditional or vernacular buildings. The earthquake energy was not propagated by radial means but spreads irregularly according to the density of the soil layer. By this way, the earthquake has different effects in some surrounding areas. Soft soils easily enlarge the wave energy displacement of the shear forces of the hypocenter. The horizontal ground peak acceleration in the area ranges from 0.20 to $0.34 \mathrm{~g}$ in the vertical direction. While an acceleration sufficiently achieves the structural destruction in the range of 0.18 to $0.30 \mathrm{~g}$. Thus the Java earthquake has a very high destructive power (Amr S Elnashai et al., 2007).

148,440 houses from the total population of 218,345 (67.9\%) of houses in Bantul could not be occupied because severely damaged and collapsed (Bappenas, 2006). The structure of the houses in the 
area was fragile and built without consideration of the earthquake. According to Boen (Boen, 2006), collapsed houses from the Java earthquake in 2006 was commonly built with brick walls either with or without a reinforced concrete frame. Most of the deaths and injuries were caused by the collapse of the brick building without reinforcement (EERI, 2006). Weak brick-walls are a major factor causing the collapse of the building. In the case of newer homes with reinforced concrete, improper structural connection are the most prominent aspects of structural failure. The most prominent causes of damage to buildings are (Amr S Elnashai et al., 2007): (a) Failure on wall angle and corner of door and window opening, (b) Roof system that shifts from the supporting wall, (c) The occurrence of broken shear or cracked masonry walls, (d) Failure in the connection area between roof, wall and foundation.
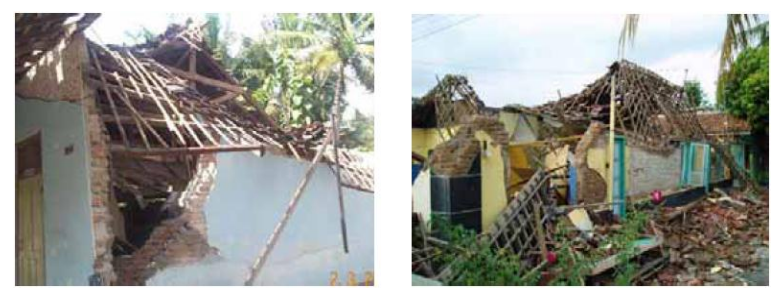

Fig. 11. The broken brick walls (photo: Boen)
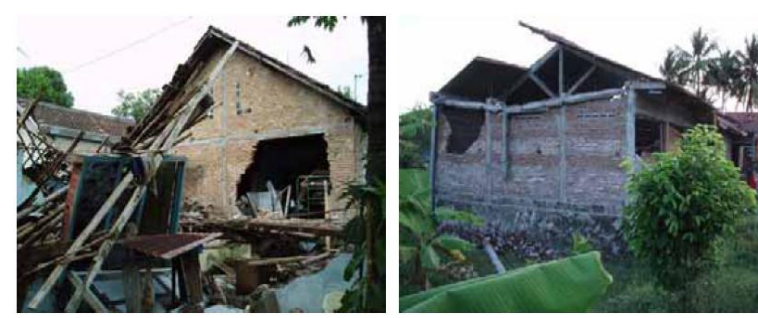

Fig. 12. The broken concrete frames (photo: Boen)

According to EERI (EERI, 2006), Javanese houses can be divided into three general categories according to their structural system; (1) Buildings with brick walls and wooden frames which were commonly found as old houses built mostly before the 90 with terracotta tiles. (2) Buildings with brick walls entirely or partially framed by reinforced concrete with the use of wooden or bamboo frames on the roof in the 90's. (3) Moreover, lately, the wooden frames are replaced by brick walls and concrete frame on the roof (Figure.11, 12). Nevertheless, although the brick walls houses with reinforced concrete frames were constructed relatively well, the fact that many damaged houses were still found for several reasons regarding the massive structure, the structural completeness, and its connection (Boen, 2006).
The primary structural system used for the building under the roof is associated with the function of the space in which the most activities are carried out. In tropical countries, two essential parts of the building are the primary structure under the roof and the roof itself. The roof is mostly built with a high slope and even sometimes more than the underlying structure. Irregularity or incompleteness of the primary structure will directly affect the vulnerability of the house since the structure provides space for the residents as well as supporting the roof load. The incompleteness of the primary structure can be missing or incomplete columns, no envelope walls, heavy wall usage, poor thin wall usage, wide openings, and complicated plans (Idham, 2014).

\section{Incomplete System}

A simple frame with the walls mostly utilizes columns on single-story buildings with the reinforced concrete frame. In some cases, especially in modern vernacular homes, columns are easy to be removed due to a complex spatial arrangement or just because of the additional space either built with the same or different materials. This missing or incomplete column will immediately reduce the compactness of the building.

\section{Connection Failure}

The failure caused by the construction between reinforced concrete columns and weak beams and between the columns and the walls. In heavily damaged homes, failures were commonly found in the connections which did not incorporate building frames and walls due to lack of the anchorages between columns and walls. All the connections both in the structural system and architectural elements should be tied. RC connection should be made by more enforcement to make sure its rigidity. Weak connection between the parts of the house, which are columns and walls, with the roof and between the walls itself. Brick wall houses using different materials such as steel or wooden columns and beams have undermined structural integrity due to the nature of different materials. Likewise, lightweight wood frames usually are not fastened firmly on the roof, so if an earthquake occurs, it will quickly experience a shift. A tied building element is the key to integrate the reaction of the house under earthquakes.

\section{Untied Structural System}

Incomplete frame is commonly found in the use of PC columns without being equipped with horizontal frames or tie beams. Without this tie, the frame- 
work then cannot acts as a single unitary system since there is no unity in the reaction to the earthquake. Incomplete concrete frames especially on the upper and lower part (ring balk and sloof) is standard in new homes. However, many of them were constructed without them, so the frame only aims to support the vertical load of the building itself. If an earthquake occurs, buildings with such structures are almost equal to buildings without concrete frames at all because of the absence of elements which keep the integrity of the building from the lateral force of the earthquake. As a result, many of these buildings were heavily damaged or even collapsed because there were no strong ties to the system and the walls. A complete and closed frame should be utilized to make sure the integrity.

\section{No External Wall}

For tropical houses, the absence of the outer walls is typical to remove indoor moisture. This circumferential wall, although not functioning directly as a significant structural element, it will increase the stiffness of the building.

\section{Heavy-Massive Walls}

The massive wall is a brick wall used in the traditional construction by using one or three-quarters of stone construction (two or one and a half layers of brick on the width of the wall) without the use of columns, without a sufficient anchor, or installed with using a wooden frame.

\section{Thin-Weak Walls}

Conversely, the thin walls constructed without enough reinforcement can also weaken the structural system of the building. These thin walls are mostly installed in the conventional brick houses which should be considered by the thick walls used to hold the roof weight. Even with the use of reinforced concrete frames, it cannot overcome the lateral force of the earthquake. This case of failure was commonly found in the new houses with the single layer masonry bricks $(12-13 \mathrm{~cm}$ with plaster, $10-11 \mathrm{~cm}$ without plaster). The height of the wall, in general, was more than $3 \mathrm{~m}$ with additional walls on the roof as high as 1-2 meter in buildings with a saddle roof shape. A thicker brick wall is not recommended since it is heavy. The additional anchorages should be installed to tie the walls with the frame.

\section{Wide Openings}

The wide openings either for a window or a door between two vertical frames will reduce the building stiffness. Building with the wide openings is relatively easy to damage and collapse during the earthquake. Wide openings such as for a garage or a shop or market in multistory buildings mostly in the ground floor is known as a soft story.

\section{BUILDING SAFETY and ARCHITECT'S ROLE}

From the nature of the earthquake, the effect to the human's built environment, the damages of the buildings, to the casualties related to the event, all these issues always involving architect as the solely profession which deals with all building process. The building circle is initially starting from preliminary study, planning, designing, constructing, functioning, to the reuse of the facility is also urge architect familiar with (Preiser \& Nasar, 2008).

When an architect is involved with the initial process, the feasibility to all aspects including safety related to the social, technique and economy are discussed. Earthquake hazard will be one of the most vital aspect to be considered. Building location prone to the earthquake will drive the planning decision regarding what facility could be developed, what building type should be used, what size of the building, and the safe preference of elements and materials. Improper precaution on the initial step of the building process may lead the unexpected disaster under earthquake.

When dealing with building design, the design concept should make sure that any decision in design is not challenging the earthquake loads (JIA-JASO, 2015). Simple plan, homogenous structure, light materials, regularity in structural form, and building integrity should be used as the main principles in building design (Giuliani, 2000; Hamburger \& Scawthorn, 2006). Smart architect should consider all the possibilities to make design safe from any natural threats without forgetting the form and function and vice versa. Integrated design related to the building and the environment should reflect in the design. The damaged buildings under earthquake were frequently caused by inappropriate architectural design discussed above.

When acting in a supervision of construction, the acknowledgment should make sure that the built construction is safe when an earthquake sways. No matter the ideal precaution done in design, the false construction also lead to wrong reaction of the building when earthquake come (JIA-JASO, 2015). Technical specification should rule the process of the construction, or even the additional precaution should be taken if the original design does not yet 
accommodate the safety on the design document. Amendment for the safety is a must, and the architect hold the vital role.

When managing the use of the building, an architect should also make the function of the room is corresponding with its maximum capacity which connect to the load. Safety issues correlated with the flow of the building, emergency egress, signage, assembly point et cetera are connected directly with the architect profession. Architectural elements and furniture should be secured from falling, and the route of the emergency will minimize the casualty (NIEPR, 2007). Only an architect now well the matter of spatial as well as building elements configuration to take appropriate precaution under earthquake.

When asked to take contribution in reuse of an existing building, the architect should completely evaluate the reusability of the building in many aspects including the most fundamental one, the safety. Old building may decrease its ability to deal with the nature including earthquake. The adaptive use should consider the capability of the existing structure so if needed, the reinforcement related to the new function should be done. Existing buildings will be considered earthquake vulnerable for less than $34 \%$ of structural requirements to resist earthquake loads (Simiona, 2015). Dealing with old building even harder than building the new facility. The role of architect is vital to lead the decision it may or may not the building reuse or remove it and build the substitution.

\section{CONCLUSIONS}

Architects play a more significant role in the safety of a building than any other discipline because they define the basic concepts of planning and building design. An architectural concept is determined by taking into account all aspects including the forms and functions as well as the systems used in buildings that will affect the safety level from earthquakes. Quakes affect the form, function, and non-structural elements of the building. In the aspect of architecture and the structure, an architect also plays a critical role because building structure experts, in general, tend to meet the demand of architects rather than maintain the ideal principles of the strength of the structure.

On the other hand, the building, in general, will not be built with $100 \%$ earthquake resistant for reasons of practicality and budget. The architect's role in earthquake-safe buildings in detail is as follows: (a) traditionally, the role of an architect is as a leading actor in the process of planning and design to a process of inspection of the construction. (b) The architect is the only profession that has a complete overall view than any other in a building. Architects as team leaders who serve building owners, bring structural experts and others into the building process and also control the contractor's work for ideal building construction. (c) The role of architects has recently been extended to coverage of all of the steps in a building process from feasibility studies, planning, design, construction, maintenance, and reuse for new functions if applicable.

Thus, the architect has a crucial position that significantly affects the level of building safety against the earthquake starting from the decision of the location, choosing the appropriate building type, designing less vulnerable structure, and avoiding the complexity in building design. An architect however has bigger responsibility for the quality of basic concepts of planning and design than to the any discipline in building structures. A statistical analysis of the civil engineer prefers a simple form rather than a complicated architecture that is unfortunately preferred by most architects. Therefore, architects became an essential key in building safety against this earthquake compared with structural engineers though. Architect's creativity should not sacrifice the safety of the building user.

By paying attention to the primary purpose of earthquake-safe construction, the philosophy and principles of demand and capacity performance of earthquake-resistant buildings under seismic loads are: (a) Under small and frequent vibrations, the main structural elements of the building should not be damaged, but non-structural elements may be damaged but repairable. (b) Under moderate and rare vibrations, elements of the primary structural system may experience reparable damage and other parts of the non-structural elements may also be damaged. (c) Under the big and sparse vibrations, primary structural elements can be severely damaged, but buildings still have to stand.

Building safety against earthquake hazards can be achieved by understanding the following aspects as (a) Role of architects is not on the only closed related to the functions and forms of the buildings, but also the strength as has been mentioned in the principle of Utilitas, Venustas, and Firmitas. The firmness lies not only in the strength of the structural system but also on all aspects required for each building steps including feasibility studies, planning, design, construction, utility, and adaptive reuse of buildings for different functions. (b) Buildings have different behaviors under quake shocks. Light buildings are the most suitable buildings applied in areas with high 
seismic intensity as in most parts of Indonesia. While massive buildings such as concrete are less appropriate to use because heavy and rigid buildings will be excessively impacted. (c) Traditional residential buildings have been proven following the principles of earthquake-resistant buildings because they are built with a lightweight wooden structure system. Modernization of traditional buildings should be done by not confusing the people by lightweight wood structural systems combined with heavy materials such as bricks and concrete.

\section{REFERENCES}

Bappenas. (2006). Preliminary Damage and Loss Assessment: Yogyakarta and Central Java Natural Disaster. Retrieved from https://thinkasia.org/bitstream/handle/11540/2453/damageassessment-indonesia-earthquake.pdf?sequence $=1$

BGS. (2018). How earthquakes affect buildings. Retrieved November 30, 2018, from https:// www.bgs.ac.uk/discoveringGeology/hazards/ear thquakes/howAffectBuildings.html.

Boen, T. (2006). Yogya Earthquake 27 May 2006, Structural Damage Report. Retrieved from https://www.eeri.org/lfe/pdf/indonesia_yogya _structural_damage.pdf.

Britanica. (2018). Earthquake - Geology. Retrieved November 29, 2018, from https://www.britannica.com/science/earthquake-geology/Properties-of-seismic-waves.

Coburn, A., Spence, R. J., \& Pomonis, A. (1992). Factor determining human casualty levels in earthquake: Mortality prediction in building collapse. In Earthquake Engineering, Tenth World Conference. Rotterdam. Retrieved from http://www.iitk.ac.in/nicee/wcee/article/10_vol 10_5989.pdf.

EERI. (2006). EERI Special Earthquake Report-. Retrieved from https://www.eeri.org/lfe/pdf/ indonesia_java_eeri_prelim_report.pdf.

Elnashai, A.S., \& Di Sarno, L. (2008). Fundamentals of Earthquake Engineering. England: A John Wiley \& Sons, Ltd, Publication.

Elnashai, A.S., Kim, S.J., Yun, G.J., \& Sidarta, D. (2007). The Yogyakarta Earthquake of May 27, 2006. Retrieved from http://mae.cee.illinois.edu/ publications/reports/Report07-02.pdf.

Ghaidan, U. (2002). Earthquake-Resistant Masonry Buildings; Basic Guidelines for Designing in Iran. Paris: UNESCO. Retrieved from http://unesdoc.unesco.org/images/0013/001324/132475EB .pdf.

Giuliani, H. (2000). Seismic Resistant Architecture: A Theory for the Architectural Design of Buildings in Seismic Zones. In 12WCEE. Retrieved from http://www.iitk.ac.in/nicee/wcee/article/2456.pdf Guevara-Perez, L.T. (2012). "Soft Story" and "Weak Story" in Earthquake Resistant Design: A Multidisciplinary Approach. In 15WCEE. Lisboa. Retrieved from https://www.iitk.ac.in/nicee/ wcee/article/WCEE2012_0183.pdf

Hamburger, R., \& Scawthorn, C. (2006). Seismic Design of Buildings, in Earthquake engineering for structural design. (W.-F. Chen \& E. M. Lui, Eds.). USA: Taylor \& Francis Group.

Idham, N.C. (2014). Prinsip-Prinsip Desain Arsitektur Tahan Gempa. (Ignas, Ed.) (1st ed.). Yogyakarta: Penerbit Andi.

Idham, N.C., \& Mohd, M. (2018). Eartquake Vulnerability Level of Reconstructed Houses, Lesson Learned after Ten Years Java Eartquake 2006. SHS Web of Conferences, 41, 06004. https://doi.org/10.1051/shsconf/20184106004

IRIS. (n.d.). Buildings and earthquakes-Which stands? Which falls? Retrieved from www.exo.net.

JIA-JASO. (2015). Earthquake-resistant Design for Architects. (M. Asano, K. Adachi, T. Okoshi, S. Kurakawa, W. Kuroda, J. Nakata, ... F. Y, Eds.) (Revised). Tokyo: Shokukusha. Retrieved from http://www.jaso.jp/pdf/eaethquake_resistant.pdf.

Krisnanto, E. (2009). Keandalan Struktur Bangunan terhadap Gempa Bumi Pada Bangunan Rumah Tinggal Padat Penduduk di Perkotaan. Jakarta: Jurusan Pendidikan Teknik Arsitektur Program Studi D3 Teknik Arsitektur Perumahan Fakultas Pendidikan Teknologi Dan Kejuruan Universitas Pendidikan Indonesia.

Maer, B.W. (2009). Respon Pendopo Joglo Yogyakarta Terhadap Getaran Gempa Bumi. Dimensi (Journal of Architecture and Built Environment), 36(1), 1-9. https://doi.org/10.9744/ DIMENSI.36.1.PP. 1-9.

Murty, C.V., Goswani, R., Vijayanarayanan, A., \& Mehta, V. V. (2012). Some Concepts in Earthquake Behaviour of Buildings. Gujarat: Gujarat State Disaster Management Authority. Retrieved from http://www.iitk.ac.in/nicee/IITKGSDMA/EBB_001_30May2013.pdf.

NIEPR. (2007). For functional improvement of school facilities for disaster prevention. Retrieved from https://www.nier.go.jp/shisetsu/pdf/ebousaitsuiki.pdf.

Oskin, B. (2018). Japan Earthquake \& Tsunami of 2011: Facts and Information. Retrieved December 2, 2018, from https://www.livescience.com/ 39110-japan-2011-earthquake-tsunami-facts. html.

Poland, M. (2010). Localized Surface Disruptions Observed by InSAR during Strong Earthquakes in Java and Hawai'i. Bulletin of the Seismo- 
logical Society of America, 100(2), 532-540. https://doi.org/10.1785/0120090175.

Preiser, W.F.E., \& Nasar, J. (2008). Assessing Building Performance: Its Evolution from PostOccupancy Evaluation. Article in International Journal of Architectural Research. https://doi. org/10.26687/archnet-ijar.v2i1.179.

Prihatmaji, Y.P. (2007). Perilaku Rumah Tradisional Jawa \& quot; Joglo \& quot; Terhadap Gempa. Dimensi (Journal of Architecture and Built Environment), 35(1), 1-12. https://doi. org/10.9744/DIMENSI.35.1.PP. 1-12.

Silva, W. (1997). Characteristics of Vertical Strong Ground Motions for Applications to Engineering Design. In I. M. Friedland, M. . Power, \& R.L. Mayes (Eds.). NCEER. Retrieved from http:// www.pacificengineering.org/nceer/Characteristi cs of vertical strong ground motions.pdf.

Simiona, M. (2015). Adaptive Reuse, an Introduction to Seismic Architecture. Auckland: myarchitects. Retrieved from www.myarchitects.co.nz.

Smart, C. L. (n.d.). Earthquakes. New York: Kean University. Retrieved from https://www.kean. edu/ csmart/Observing/06. Earthquakes.pdf.

Spence, W., Sipkin, S. A., \& Choy, G. L. (2018). Measuring the Size of an Earthquake. Retrieved November 29, 2018, from http://sappho.eps. mcgill.ca/ olivia/EES/2018-Winter/magnitudes. pdf.
USGS. (n.d.). Magnitude/Intensity Comparison. Retrieved November 29, 2018, from https://earthquake.usgs.gov/learn/topics/mag_vs_int.php.

USGS. (2016). Measuring Earthquakes. Retrieved November 29, 2018, from https://pubs.usgs.gov/ gip/earthq1/measure.html.

USGS. (2018). Earthquake Lists, Maps, and Statistics. Retrieved December 2, 2018, from https://earthquake.usgs.gov/earthquakes/browse/

Walter, T. R., Wang, R., Luehr, B.-G., Wassermann, J., Behr, Y., Parolai, S., ... Zschau, J. (2008). The 26 May 2006 magnitude 6.4 Yogyakarta earthquake south of Mt. Merapi volcano: Did lahar deposits amplify ground shaking and thus lead to the disaster? Geochemistry, Geophysics, Geosystems, 9(5), n/a-n/a. https://doi.org/10. 1029/2007GC001810.

White, J. (n.d.). Five reasons buildings fail in an earthquake-and how to avoid them. Healthcare Design Magazine. Retrieved from https://christnerinc.com/uploads/wysiwyg/hcd-five-reasonsbuildings-fail-during-earthquakes-jeff-white.pdf.

Yashinsky, M. (2006). Earthquake damage to structures. In W. Chen \& E. Lui (Eds.), Earthquake engineering for structural design (p. 158.). Boca Raton: Talyor \& Francis. 